\title{
Polygyni i Egypt mellom regjering og disiplinær makt
}

Klassisk sharia tillater mannen å ha opptil fire koner, i strid med moderne idealer om kjærlighet og trofasthet som grunnlag for ekteskap. Staten i Egypt forsøker likevel å forby og begrense polygyni.

Av Monika Lindbekk, assisterende foreleser ved Det britiske universitetet i Egypt.

Temaet for denne artikkelen er rettsutviklingen når det gjelder polygyni i Egypt i det 20. og 2I. århundre med utgangspunkt i lovgivning og rettspraksis. Egyptisk familierett er i vesentlig grad basert på sharia, islamsk rett. Derfor analyseres også utviklingen av sharia og dens forhold til et moderne rettssystem i lys av denne rettsutviklingen ved hjelp av en foucaultsk vinkling.

\section{Klassisk sharia}

Knut Vikør ${ }^{\mathrm{I}}$ betegner klassisk sharia som en juristskapt rett. Den består av et sett med åpenbaringskilder og en vitenskap for å lage regler ut fra disse kildene. Den fremste kilden til regler er åpenbaringen som består av Koranen og Sunnah. Koranen er Guds ord i direkte tale. Sunna består av Profeten Muhammeds normative utsagn og handlinger. I praksis er den islamske retten blitt utviklet gjennom århundrene av lærde kjent som ulama (rettslærde) tilhørende ulike rettsskoler. De utviklet rettsregler ut i fra åpenbaringen i henhold til en vitenskap kalt usul al-fiqh (rettens røtter). Den islamske rettens fire røtter er Koranen, sunna (profeten Muhammads normative utsagn og handlinger), konsensus blant de rettslærde (ulama) (ijma) og ijtihad som i vid betyd- ning betyr menneskelig strev for å utvikle loven. Det er en utbredt mening at den islamske rettsvitenskapen (figh) stagnerte mot slutten av det niende århundre. Ijtihad antas etter formingsperioden å ha veket for en periode preget av taqlid, hvilket betyr etterligning av fortidens rettslærde (ulama).

\section{Polygyni i henhold til klassisk sharia}

Klassisk sharia er blitt definert som et system av plikter som de rettslærde plasserte i ulike kategorier. ${ }^{2}$ Bare to kategorier er av juridisk betydning, nemlig det lovlige (halal) og det ulovlige (haram), Innenfor feltet av det lovlige gjøres flere etiske distinksjoner som henvender seg til individets samvittighet. Det skjelnes mellom obligatoriske handlinger, tilrådelige handlinger (mandub) og klanderverdige handlinger (makruh). Det finnes også en kategori av handlinger som er tillatt (mubah) uten moralsk relevans, det vil si at de verken er positivt eller negativt ladet. Den muslimske manns tillatelse til å ha fire koner faller inn under denne kategorien.

Koranen tillater mannen å ha fire koner på den betingelse at han behandler dem rettferdig. ${ }^{3}$ Når det gjelder sunna, den andre rettskilden, ba Muhammad konvertitter som hadde mange koner om å beholde fire og skille seg med resten. ${ }^{4}$ 
Samtlige rettsskoler tillater også en mann å være gift med fire koner samtidig. Det er konsensus om at det $\mathrm{i}$ kravet om rettferdighet ligger en moralsk, men ikke en rettslig begrensning, av tillatelsen til polygyni. ${ }^{5}$ Den rettferdighet det dreier seg om angår ytre former slik som for eksempel forsørgelse og fordeling av tid mellom konene. Rettferdighet angående følelser er ifølge Gud umulig å oppnå. ${ }^{6}$

Den moralske begrensningen på polygyni er altså knyttet til kravet om rettferdighet. Ifølge en av rettsskolene, nemlig Maliki-skolen, kan også en kone få skilsmisse på grunnlag av skade dersom hun blir behandlet urettferdig. ${ }^{7}$ Kvinner har dessuten mulighet til å avverge polygyni ved å innføre en klausul i ekteskapskontrakten om at ektemannen ikke skal kunne ta en ny kone. ${ }^{8}$

Fra klassisk sharia til statlig lovkodifikasjon I det I9. århundrets Egypt så man fremveksten av en moderne stat. Lovkoder bestemt av statlige organer ble gradvis innført på områder som sivil- og strafferett. ${ }^{9}$ Dette medførte at sharias virkeområde ble gradvis begrenset til spørsmål om familieog arverett, og islamske stiftelser (waqf).

Moderne statlige rettssystem er basert på doktrinen om statsborgerskap og forestillingen om et autonomt rettssubjekt. Individet er i stand til å handle med fri vilje og viten om at han/hun må bære ansvaret for sine handlingsvalg i overensstemmelse med eller i opposisjon til statlig lovgivning. Det er en klar motsetning mellom dette subjektet og individer som er sterkt bundet til strukturer som for eksempel familie hvor kvinner og barn kan være underlagt familiefarens myndighet.

Jeg benytter Foucaults hypotese om regjering og disiplinær makt som teoretiske instrumenter i min analyse. Foucault mente at moderne former for makt kan sammenholdes i en trekant av tre maktformer; suverenitetsmakt, disiplin og regjering. ${ }^{\text {Io }}$ Suverenitetsmakten hersker gjennom lovgivning som er et instrument for å kommandere undersåttene til lydighet støttet av trussel om sanksjoner. Dette er ikke tilstrekkelig til å beskrive måten makten - og i forlengelse av dette retten - opererer på i moderne samfunn, mener Foucault, og hevder at det moderne individ er formet av maktrelasjoner som går under samlebetegnelsen «biomakt». Biomakt har i følge Foucault ${ }^{\text {iI }}$ utviklet seg $i$ to hovedformer. Den ene døpte han befolkningens bio-politikk. Den andre kalte han disiplinoer makt.

Mot slutten av det I8. århundret mente Foucault å se utviklingen av en ny politisk rasjonalitet i Europa der stater la økt vekt på at de ikke bare hadde å gjøre med undersåtter, men med en befolkning. ${ }^{12}$ Prosjekter for befolkningskontroll ble knyttet til en form for politisk rasjonalitet som Foucault kalte regjering. Regjering er en oversettelse av Foucaults' begrep «governmentality» som innebærer at regjering er forbundet med mentaliteten til de styrte. ${ }^{\mathrm{I}}$ Jeg vil vise at «governmentality» er en styringsform som i økende grad griper inn i familieretten i Egypt slik den berører rettssituasjonen for polygyni.

\section{Foucaultisk vinkling på egyptisk familierett} Familien inntok en sentral plass innen befolkningskontroll. Tidligere hadde kone, barn og resten av husholdningen vært underlagt autoriteten til familiefaren. ${ }^{\mathrm{I}}$ Denne anordningen har fått redusert betydning etter hvert som de økonomiske prosessene 
og politiske strukturene ikke lenger kunne finne et skikket redskap eller en tilstrekkelig støtte i den. ${ }^{15}$ Familien skulle fortsatt være et viktig instrument for regulering, men den måtte reorganiseres på moderne grunnlag slik at den ble «of secondary importance compared to the population». ${ }^{16}$

I Europa skjedde det i det I9. århundret en «diskursiv eksplosjon» når det gjaldt seksualitet. ${ }^{17}$ Foucault beskriver hvordan seksualiteten ble forfulgt inn i dens minste detaljer i form av medisinske eller psykologiske eksaminasjoner av blant annet homoseksuelle menn. Deretter ble deres avvik forsøkt disiplinert bort i henhold til denne individualiserte viten. ${ }^{8}{ }^{8}$ Dette kalte Foucault disiplinær makt. Språkliggjøringen av seksualiteten oppstår i følge Foucault innenfor det han omtaler som seksualitetsanordningen på I700-tallet. Der er det ikke reproduksjon og arv, men det følelsesmessige forholdet mellom medlemmene av kjernefamilen (en gruppe bestående av foreldre og barn) som blir det sentrale. ${ }^{19}$ I tillegg til å bryte opp allianseanordningen, har denne diskursen om følelser hatt som konsekvens å undergrave familiens patriarkalske struktur ved at mannens innflytelse over konen ble avhengig av den kjærlighet og respekt hun følte for ham. ${ }^{2 \circ}$ Dette bidro til dannelsen av kvinner som autonome individer.

I Egypt har det funnet sted en liknende utvikling. I det I8. århundrets Egypt utøvet familier kontroll i fravær av en sentralisert stat med byråkrati på en måte som kan sammenlignes med situasjonen i det føydale Europa, ${ }^{2 \mathrm{I}}$ det Foucault kalte allianseanordningen. Myndighetenes interesse for ekteskapelig seksualitet falt sammen med fremveksten av forvaltningsteknikker med fokus på regulering av befolkning i stedet for undersåtter i det I9. århundret. ${ }^{22}$ Mens man tidligere mente at familien kunne klare seg selv, ble den egyptiske familiens velferd i løpet av det I9. århundret i økende grad forbundet med velferden til befolkningen som helhet. Det var i denne perioden polygyni ble definert som et sosialt problem. Ordningen ble oppfattet som å være i strid med idealet om kjærlighet og trofasthet som grunnlag for ekteskap.

Parallelt med den rettslige sentraliseringen, utviklet islamske reformatorer en ny forståelse av sharia. Hjørnestenen i deres prosjekt var å gi økt rom til ijtihad. Dette var rettet mot taqlid (etterligning) og ijma (konsensus) som reformatorene mente

\section{Koranen tillater mannen å ha fire koner på den betingelse at han behandler dem rettferdig.}

gjorde de islamske rettslærde (ulama) ute av stand til å håndtere moderne utfordringer. De mente at åpenbaringen skulle tolkes i lys av samfunnsnytte (maslaha). Formålet med ekteskapet innen klassisk sharia er seksuell tilfredsstillelse og å sette barn til verden. $^{23}$ Den klassiske islamske familieretten er påvirket av tidens sedvane ved at slektskap i mannslinjen gis rettighetsdefinerende betydning og myndigheten over familiemedlemmene ligger hos faren. Islamske reformatorer integrerte idealet om kjærlighet som grunnlag for ekteskap i sharia på en selektiv måte som de hevdet var i overensstemmelse med Koranen og sunna. I forholdet mellom ektefellene 
vektla den betydningsfulle egyptiske reformatoren Muhammad Abduh verdier i islamsk språkdrakt som nåde (rahma) og vennskapelighet (mawadda). Samtidig var Abduh svært kritisk innstilt til polygyni. Han mente det hadde utviklet seg til å bli en skadelig praksis som burde forbys med unntak av bestemte tilfeller. Dette til tross for at polygyni er tillatt av Koranen og sunna. ${ }^{24}$

Samtidig som modernistene ønsket å gjenopplive islamsk tradisjon, forsvarte de trenden $\mathrm{i}$ retning av kodifisering og moderne domstoler med at det var nødvendig for å etterkomme tidens krav. De mente at også familieretten burde kodifiseres. Ved hjelp av reformatorenes doktriner, ble den rekonstruerte shariaen integrert i egyptisk familielovgivning. I I955 ble sharia-domstolene som dømte i saker om familierett oppløst, og familierett anvendes i dag av dommere i statlige domstoler uten bakgrunn i fiqh (islamsk rettslære). Familielovgivning og rettshåndhevelse er blitt elementer i en politisk strategi som forsøker å forme folks oppførsel ved å konstruere forutsetninger for handling. I det følgende vil jeg se på hvordan lovgiver, dommere og advokater bruker Sharia.

Alan Hunt og Gary Wickham ${ }^{25}$ ser likheter mellom Foucaults' hypotese om ansvarliggjørende «governmentality» som en maktteknikk og rettsliggjøring, utviklingen der retten påvirker stadig flere områder av samfunnet. Det som endrer rettens rekkevidde er i følge dem at maktteknikkene lov og normalisering smelter sammen med hverandre. Retten virker normaliserende ved å indikere hvilke normer den ønsker å støtte. I Europa har dette kommet til uttrykk i lovgivning som gjør det lettere å få skilsmisse fra følelses- messig utilfredsstillende ekteskap til tross for religiøs og moralsk motstand..$^{26}$ Loven styrer her subjektet på en måte som ikke er basert på vilkårlig autoritet, men på menneskets «sanne» natur. Dette er i overensstemmelse med ideen innenfor liberal statsteori om at rettssubjektet er i stand til å gjøre autonome valg.

Innholdet av normene spiller imidlertid ingen rolle. Loven kan for eksempel inkorporere islamsk moral basert på en oppfatning av individet som moralsk. «What is important is that the law helps guide/coerce/encourage/induce individuals towards certain ways of doing right and away from certain ways of doing wrong, even where flexibility is required. ${ }^{27}$ Jeg vil hevde at den egyptiske staten både spiller på et psykologisk og et moralsk register av virkemidler i behandlingen av polygyni.

\section{Artikkel II i lov nr. Ioo fra 1985}

Som nevnt foreligger den egyptiske familieretten i dag stort sett i skrevne lover. ${ }^{28}$ Polygyni blir beskrevet av lovgiver som et sosialt problem. Det har imidlertid vist seg vanskelig å begrense en praksis som er tillatt av klassisk sharia. Gjentatte forsøk på å begrense polygyni på I920-, 40-, og 50-tallet ble skrinlagt. Teknikker for styring ble bestridt i den bitre politiske striden omkring Sadats lov av I979. Denne loven utvidet Maliki-skolens begrep om skade til å omfatte polygyni. Loven ble ansett for å være i strid med sharia da den gjorde polygni i seg selv til en skilsmissegrunn. Bestemmelsen ble også motarbeidet av dommere og vanlige folk som følge av en endring i konstitusjonen fra I98I som går ut på at sharia skal være den fremste kilde til lovgivning. Dette førte til en modifisering av lovverket $\mathrm{i}$ form av lov nr. Ioo fra 
I985. Artikkel II i lov nr. Ioo fra I985 opprettholdt tillatelsen til polygyni, men for å blidgjøre det internasjonale samfunn, blant andre FN med sin agenda om frihet og likestilling, ble polygyni vanskeliggjort gjennom innføring av informasjonsplikt. Man lovfestet også konens rett til skilsmisse dersom hun kunne bevise at hun hadde lidd materiell eller immateriell skade som følge av polygyni.

Som nevnt er ekteskap på grunnlag av kjærlighet kjernen i det vestlige familieideal, og dette oppfattes som viktig for å produsere moderne autonome borgere. Dette står i kontrast til klassisk sharia som tillater mannen å ha fire koner og en tilnærmet ubegrenset rett til skilsmisse uten at kvinnen har tilsvarende rett til skilsmisse. Talal $\mathrm{Asad}^{29}$ hevder at de arabiske lovreformene har vært inspirert av det vestlige ideal om kjærlighet som grunnlag for ekteskap. I motsetning til dette mener Kamran Asdar $\mathrm{Ali}^{30}$ at den egyptiske staten fortsatt ønsker seg menn som familieoverhoder, men hans lojalitet må ligge hos staten og de må være sosialt ansvarlige. Jeg vil hevde at begge disse strategiene er representert i artikkel II.

Artikkel i lov nr. Ioo fra I985 oppfatter jeg som en maktstrategi med to dimensjoner. I stedet for tvang, styrer de folk i ønsket retning. Ifølge Foucault ${ }^{31}$ og Rose $^{32}$ har det religiøse rammeverket omkring seksuell moralitet til dels forsvunnet i Europa, og blitt erstattet av blant annet psykologiske normer. Den første dimensjonen består av en alternativ form for regjering som har inkorporert islamsk moral i et forsøk på å forbedre polygyni basert på en oppfatning av mennesket som moralsk. Den andre går i retning av å forby polygyni gjennom å støtte psykologiske normer basert på en oppfatning av mennesker som psykologiske subjekter.

\section{Første dimensjon: forbedring av polygyni}

Den første strategien går ut på å opprettholde menns tillatelse til polygyni, men å forbedre denne praksis ved å holde den innenfor sin «legitime» ramme. Man har fått en nærmere syntese mellom rett og islamske moralske standarder hvis overholdelse tidligere var overlatt til den enkelte troendes samvittighet. Dette gjelder oppfordringen til polygame menn om å behandle konene rettferdig. Staten ønsket ikke å overlate spørsmålet om rettferdighet til mannens samvittighet. Derfor gjorde den det mulig for en kone å få skilsmisse på grunnlag av skade dersom kravet om rettferdighet ikke oppfylles. Dermed er en moralsk standard som i henhold til fiqh ikke er rettskraftig, blitt rettsliggjort. ${ }^{33}$

Vanligvis baserer dommerne sine rettsbeslutninger på lovgivning og høyesterettspraksis. Tidvis legitimerer de imidlertid sine rettsbeslutninger med henvisning til sharia. Egypts Høyesterett forbinder tillatelsen til polygyni med et ideal om en polygam ektemann som er rettferdig og måteholden. Staten forsøker her å løse et sosialt problem ved å kalle menn til ansvar for det felles beste. Høyesterett forsøker også å forhindre følelser som sjalusi i å undergrave polygame ekteskap. I den forbindelse har jeg også sett en rettsbeslutning i førsteinstans legitimert ved å vise til polygyni som en løsning på det antatt økende antall enker, skilte og enslige kvinner, noe som blir betraktet som et sosialt problem. Dommeren mener kvinner som søker om skilsmisse fordi de føler seg fornærmet av polygyni mangler innsikt i sharia og betegner dem som egoistiske. 
Han avslutter ved å sitere en hadith hvor Profeten sterkt fraråder skilsmisse. Dette er eksempler på det Foucault kalte «governmentality» ved at teknikker for dominans forbindes med selvforholdsteknikker, i dette tilfellet ved å holde frem idealer om moralske subjekter med islamske dyder. Slik fremtrer polygyni som et sosialt problem først når mannen svikter som familieoverhode.

\section{Andre dimensjon: forbud mot polygyni}

Den andre tendensen går i retning av å forby polygyni og erstatte det med monogami. Kvinnen kan få skilsmisse dersom hun beviser at hun lider materiell eller immateriell skade som følge av det nye ekteskapet. Det har her skjedd en sammensmelting mellom rett og psykologiske normer ved at det fremstår som viktig å frigjøre kvinner ikke bare fra materiell skade, men også fra moralsk og psykologisk skade. «Psykologisk skade» ble først nevnt i forlaringsnotatet utferdiget av komiteen som sto bak lovforslaget fra i985. Ifølge forklaringsnotatet til lovforslaget omfatter immateriell skade moralsk og psykologisk skade. Denne dimensjon bygger på et begrep om mennesker som psykologiske subjekter og har som mål å skape følelsesmessig tilfredsstilte individer. Dette bidrar til konstruksjon av kvinner som autonome individer, som borgere i en nasjonalstat der de ikke betingelsesløst er underlagt ektemannens myndighet. Dette har klare likhetstrekk med lov nr. 44 fra I979 som erklærte at polygyni er skadelig og er å anses som grunnlag for skilsmisse i seg selv. Dette kan også sammenlignes med en lovmekanisme fra 2000 som gjør det mulig for en kvinne å få skilsmisse uten mannens samtykke selv om det ikke fore- ligger materiell skade mot at hun tilbakebetaler medgiften.

Utvidelsen av rettslig makt til å dekke dette området ble legitimert med blant annet henvisning til det generelle islamske prinsippet «No harm shall be inflicted or reciprocated in Islam». Fordi klassisk sharia er definert som et system av plikter, inngår imidlertid ikke følelser i dette systemet. Når det gjelder polygyni har Forfatningsdomstolen derfor tolket begrepet immateriell skade på en innskrenkende måte, slik at bestemmelsen om skade kun gjelder tilfeller hvor mannen forlater konen.

Dommere i første instans anvender loven på en måte som er i strid med klassisk sharia og forutsetningene til Forfatningsdomstolen og Høyesterett. Dommerne orienterer seg til dels etter skadens

Mannens gudegitte rettighet er blitt modifisert ved at kvinnen kan få skilsmisse selv om mannen behandler konene rettferdig.

sosialt relevante egenskaper som kan gi den status som det Baudouin Dupret ${ }^{34}$ kaller «normal skade». Kategoriene moralsk og psykologisk skade, som ble introdusert i lovgivers forklaringsnotat, har på den måten dukket opp igjen i de lavere instanser i strid med Forfatningsdomstolen og Høyesteretts forutsetninger. Polygyni blir i den forbindelse problematisert av dommere i henhold til måten det rammer konens ære, status og følelser.

I strid med Forfatningsdomstolen og Høyesteretts forutsetninger, fremstår det 
som viktig for dommere i førsteinstans å frigjøre kvinner ikke bare fra materiell skade, men også fra moralsk og psykologisk skade. Psykologisk skade kan for eksempel omfatte sårethet, hat og sjalusi. Mannens gudgitte rettighet er således blitt modifisert ved at kvinnen kan få skilsmisse selv om mannen behandler konene rettferdig. Dommerne tar også i betraktning ektemannens motiver og konens intensjonelle rolle i handlingsforløpet som ledet frem til det nye ekteskapet. Dersom hun er ulydig, har hun selv valgt å gi årsak til det nye ekteskapet, og hun mister retten til skilsmisse på grunnlag av psykologisk skade. Dette innebærer at ekteskapet fortsatt er basert på et asymmetrisk forhold mellom ektefellene, selv om det skal være basert på kjærlighet. Dette fokuset på mannen som familieoverhode og følelser er også et gjennomgangstema i lovforarbeid, rettsvitenskap, og kursene som ekspertene i familiedomstolene må gjennomgå. Selv om vektleggingen av psykologisk skade klart går utover reglene innen klassisk fiqh, mente dommere at de anvendte sharia og påberopte seg Koranen og sunna. ${ }^{35}$

\section{Rettspraksis og sosioøkonomiske forhold}

Rettspraksis kan ikke studeres isolert fra et større nettverk bestående av diskurser og praksiser rettet mot seksualitet. Dupret ${ }^{36}$ mener at fordi dommerne ikke har bakgrunn i fiqh (islamsk rettslære), skiller deres islamske diskurs seg ikke mye fra den til lekfolk. I løpet av det 20. århundret ble det nye idealet hvor individer gjør et livsvarig valg av ektefelle på grunnlag av gjensidig kjærlighet og tiltrekning, styrket gjennom populære medier som film og egyptisk fjernsyn og offentlig utdannelse. ${ }^{37}$
Disse kan forstås som teknikker som bidrar til å konstruere moderne individer gjennom en diskurs om følelser.

Det er også et komplisert samspill mellom retten og islamistiske diskurser. Islamister har tilegnet seg og gjengir moderne ideer i større grad enn man først kan få inntrykk av for eksempel ved at hovedvekten ikke lenger legges på den seksuelle tilfredsstillelsen og reproduksjonen, men på gjensidig kjærlighet. I følge Abu-Lughod $^{38}$ bruker de uttrykkene mawadda (vennskapelighet) og rahma (nåde) for å beskrive forholdet mellom ektefellene. Det gjorde, som nevnt, også reformatoren Muhammad Abduh (se ovenfor). Ifølge Abu-Lughod benytter noen islamister også ordet kjærlighet (hubb). Samtidig vektlegger de et asymmetrisk forhold mellom ektefellene. Dette er, som nevnt, også et gjennomgangstema i lovforarbeid, rettsvitenskap, kursene som ekspertene i familiedomstolene må gjennomgå, og i rettspraksis angående skade som følge av polygyni. ${ }^{39}$

Polygyni blir med dette av islamistene i økende grad sett på som et avvik fra normen som må forklares med grunner uten bakgrunn i islamsk rettsvitenskap (fiqh) (som nevnt finnes det innen islamsk rettsvitenskap kun et moralsk krav om rettferdig behandling): for eksempel at antall kvinner overstiger antall menn, at den første konen er steril, syk eller ulydig. På grunn av en ubalanse i ekteskapsmarkedet er det ifølge Fargues $^{40}$ sannsynlig at flere kvinner vil gifte seg for første gang med skilte eller polygame menn. Man kan imidlertid også komme til å se en økning i kvinner som aldri gifter seg.4 ${ }^{4}$ Dette har skapt bekymringer for at den moralske orden står i fare for å bli undergravet. Dette 
gjelder også representanter for ulama (rettslærde), ofte kalt tradisjonens voktere, som jeg intervjuet. Den forhenværende statsmufti Shaykh Gad el Haqq Aly alHaqq ${ }^{42}$ oppfordret unge menn i giftemoden alder til å ta flere koner som en mulig løsning på problemet med overtallige kvinner - på betingelse av at de behandlet konene rettferdig.

\section{Retten som regjering}

Retten som regjering har også innlemmet disiplinære teknikker. Etter opprettelsen av den nye familiedomstolen høsten 2004 har sosiologer og psykologer fått sin ekspertise tilknyttet de rettslige prosesser. Disse var ukjente innen klassisk sharia. De diagnostiserer årsakene til de rettslige problemene og kommer med en anbefaling til dommeren hvor vitenskapelige kriterier inngår. Dette er et eksempel på det Foucault kalte disiplinær makt. Ekspertene bidrar også med kunnskap som har gjort det mulig å bevise ting som ligger utenfor jurisdiksjonen til klassisk sharia, som for eksempel immateriell skade. Ifølge noen dommere er ekspertrapportene i seg selv tilstrekkelig bevis for psykologisk skade. På den måten bidrar ekspertene til å gjøre tillatelsen til polygyni til et tomt skall.

Også her spiller religiøse normer en legitimerende rolle. Ekspertkursene fremmer en norm om kjærlighet mellom ektefellene i islamsk språkdrakt, men beskriver samtidig forholdet mellom ektefellene som asymmetrisk ved at mannen har myndighet over hustruen.

\section{Avslutning og konklusjon}

I klassisk sharia kan en mann ha opptil fire koner samtidig under forutsetning av at han behandler dem rettferdig. Problemati- seringen av polygyni i Egypt går tilbake til det I9. århundret med utbredelse av diskurs om kjærlighet som grunnlag for ekteskap. Min konklusjon er at tolkinger av sharia er blitt integrert $i$ to ulike maktstrategier i form av moderne lovgivning. Artikkel II i lov nr. Ioo fra I985 viser en spenning mellom en strategi for å forme kvinner som autonome individer og en annen strategi basert på mannen som ansvarlig familieoverhode.

Ifølge Forfatningsdomstolen og Нøуesterett var formålet med artikkel Iı i lov nr. IO० fra I985 å bidra til at polygame menn oppfyller plikten til å forsørge sine koner og til å fordele sin tid rettferdig mellom dem. Samtidig er introduksjonen av den rettslige kategorien «immateriell skade» blitt ansett som et slu forsøk på å forby polygyni ved å gjøre det lettere å få skilsmisse fra ekteskap som ikke er følelsesmessig tilfredsstillende.

For begge retninger gjelder at lovgiver har tolket sharia på måter som møter sosiale behov. I domstolene benyttes sharia for å styrke positiv rett. Både dommere som tolker loven i samsvar med Forfatningsdomstolen og Høyesteretts forutsetninger og de som ikke gjør det, henviser til sharia på en kreativ måte for å rettferdiggjøre sine rettsbeslutninger - en religiøst ladet biomakt.

\section{$\cdot f \cdot$}

I Vikør, Knut: «Mellom Gud og stat: Ei historie om islamsk lov og rettsvesen». Oslo: Spartacus Forlag AS 2003, s. I4

2 Anderson, James Norman Dalrymple: "Law reform in the Muslim world”. University of London: The Athlone Press, I976, s. 3 .

3 «Hvis dere er redd for ikke å gjøre rett mot de foreldreløse... ta til ekte det som passer dere av kvinner, to, tre eller 
fire. Men, hvis dere er redde for ikke å kunne gjennom føre full likhet (ta'dilou), så nøy dere med en, eller med deres slavinner. Det er det mest nærliggende for å unngå å gjøre urett." (4:3) Siden Einar Bergs norske oversettelse av Koranen er noe upresis, har jeg konsultert andre oversettelser. Ordet "ta'dilou" betyr ikke så mye "likhet" som det å være "rettferdig", det som på engelsk kalles "equitable". Av den grunn benyttet jeg ordet rettferdighet i stedet for likhet i fremstillingen.

4 “Sunan Abu Dawud", bok I2, nr. 2233. Profeten tok trolig selv i alt fjorten koner, fem av hvilke var i live da han døde. Se Stowasser, Barbara Freyer: "Women in the Quran, traditions, and interpretation". New York: Oxford University Press (US), I994, s. 86.

5 Coulson, Noel J.: "Islamic law", $\mathrm{i}$ «An introduction to legal systems». Ed. J. D. M. Derrett (red.). London: Sweet and Maxwell, I968, s. 75

6 Ali, Abdullah Yusuf: «The meaning of the holy Quran». Beltsville, Maryland: Amans publications, 2000, s. 27.

7 Coulson, Noel J.: «Conflicts and tensions in Islamic jurisprudence». Chicago: University of Chicago Press, I969, s. 93.

8 Anderson, James Norman Dalrymple: «Law reform in the Muslim world». University of London : The Athlone Press, 1976, s. 49.

9 Shaham, Ron: «Family and the courts in modern Egypt». Leiden: Brill I997, s. Io.

Io Foucault, Michel: "Governmentality" i «The Foucault Effect». G. Burchell, C. Gordon and P. Miller. Chicago, University of Chicago Press, I99I, s. I02.

II Foucault, Michel: «Seksualitetens historie I: Vilje til viten». Oslo : Pax forlag, I999, s. 152.

I2 Ibid., s. 34

I3 Fransk: gouvernementalité. Ordspillet til Foucault er en sammensmeltning av "regjering" og "mentalitiet". Mens makten under suverenen til tider demonstreres med stor seremoni, er gouvernementalité både sentraliserende og individualiserende. På den ene siden dreier det seg om fremveksten av moderne statlig byråkrati. På den andre siden er det strategiske målet til denne maktformen å strukturere mulighetene for handling på en måte som fremmer ønsket oppførsel. Dette forutsetter et viktig element, nemlig frihet. Befolkningen må få utvikle seg "naturlig" uten inngrep i form av statlige befalinger. Se Foucault, Michel: "The subject and power" i Michel Foucault: «Beyond structuralism and hermeneutics». Chicago: University of Chicago Press, I982, s. 22I og Schaanning, Espen: "Regjeringskunst" i Idehistorisk tidsskrift, nr. I-2, 2005 , S. 130 .

I4 Collins, Randall: «Weberian sociological theory». Cambridge University Press, 1986, s. 287.

I5 Foucault, Michel: «Seksualitetens historie I: Vilje til viten». Oslo: Pax forlag, I999, S. II7-II8.

I6 Foucault, Michel: "Governmentality" i «The Foucault Effect». G. Burchell, C. Gordon and P. Miller. Chicago, University of Chicago Press, I99I, s. 99.
I7 Foucault, Michel: «Seksualitetens historie I: Vilje til viten». Oslo: Pax forlag, I999, s. 25.

I8 Ibid., s. I59.

I9 Ibid., s. I20.

20 Donzelot, Jacques: «The Policing of families», London: Hutchinson, I979, s. I8I.

2I Fay, Mary Ann: "The ties that bound: women and households in eighteenth-century Egypt" $\mathrm{i}$ «Women, the family, and divorce laws in Islamic history». Amira El Azhary Sonbol (red.). Syracuse, NY: Syracuse University Press, I996, s. 158 .

22 Fahmy, Khaled: "Women, medicine, and power" i «Remaking women: Feminism and Modernity in the Middle East». Lila Abu-Lughod (red.). The American University in Cairo Press, I998, s. 6I-63.

23 El Alami, Dawoud: "The Marriage Contract in Islamic Law in the Shari'ah and Personal Status Laws of Egypt and Morocco». London: Graham \& Trotman I992, s. 93.

24 Imara, Muhammad: "Al-islam wa-al-mar'a: fi ra'i al-'imam Muhammad Abduh". Cairo: Cairo for Arabic culture 1975, s. 45.Gjennom hele sin karriere problematiserte Muhammad Abduh polygyni. Abduh mente at da polygyni ble tillatt, bidro praksisen til å styrke samfunnet, men i hans egen tid hadde utartet til en praksis fordervet av lyst. Abduh beskrev polygyni på en meget negativ måte. Han hevdet at det var umulig å utdanne en nasjon hvor polygyni ble praktisert. Blant de uønskede resultater av polygyni han observerte i sin samtid, var fravær av tillit mellom ektefellene og bitterhet mellom konene som bredte seg til barn og slekt. Religion ble åpenbart til folks fordel. Dersom en av dens bestemmelser begynner å skade samfunnet i stedet for å gagne det, må bestemmelsen endres i henhold til samfunnets behov. To islamske prinsipper ble benyttet for å støtte argumentet hans om å ta opp tillatelsen til polygyni til ny vurdering. Det ene går ut å på å forhindre skade fremfor å realisere bestemte fordeler og det andre går ut på at man ikke skal påføre skade og ikke giengjelde skade med skade. Han nådde på den måten frem til den konklusjon at polygyni er et onde til tross for at det er tillatt av Koranen og ble praktisert av Profeten. Gatji, Helmet: «The Quran and its exegesis.» London : Routledge \& Kegan Paul, 1976, s. $249-250$.

25 Hunt, Alan og Wickham, Gary: «Foucault and law: Towards a sociology of governance». Pluto Press: London Sterling, Virginia, I994, s. 66

26 Stone, Lawrence: "Family history" $\mathrm{i}$ «The new history». Theodore K. Rabb og Robert I. Rotberg. Princeton, New Jersey: Princeton University Press, I982 s. 73.

27 Hunt, Alan og Wickham, Gary: «Foucault and law: Towards a sociology of governance». Pluto Press : London Sterling, Virginia, I994, S. II4

28 På områder hvor man mangler en lovbestemmelse og høyesterettspraksis står det $\mathrm{i}$ artikkel $3 \mathrm{i}$ lov nr. I fra 2000 at den fremherskende mening innen Hanafi-skolen skal gjelde.

29 Asad, Talal: "Conscripts of Western civilization", i «Dialectical anthropology: Essays in honor of Stanley Diamond, 
vol. I», C. Gailey (eds), Gainesvile, University Press of Florida, 1992, s. 336.

30 Ali, Kamran Asdar: «Planning the family in Egypt: New bodies, new selves", The American University in Cairo Press, 2002, S. I23.

3I Foucault, Michel: "On the genealogy of ethics an overview of work in progress" $i$ «Ethics, the essential works, volume one». Paul Rabinow (red.). London The Penguin Press, I997, s. 267

32 Rose, Nikolas: "Governing the soul". London New York: Free Association Books, I999, s. xxxi.

33 I Forfatningsdomstolens avgiørelse angående grunnlovsmessigheten av artikkel II fra I994, henviser den ikke til Maliki-skolen som tillot at en kvinne å få skilsmisse dersom ektemannen ikke behandlet konene rettferdig. I stedet baserte Forfatningsdomstolen sin tolkning av artikkel II på en kombinert lesning av sura 4 vers 3 og hadithen "No harm shall be inflicted or reciprocated in Islam". Forfatningsdomstolen påberoper også prinsippet om å forhindre skade fremfor å realisere bestemte fordeler og det andre. Det er verd å merke seg at flere av disse prinsippene er de samme som den islamske reformatoren Muhammad Abduh brukte i sin ijtihad angående polygyni. Se n. 24 .

34 Dupret,Baudouin: "The practice of judging”, upublisert artikkel, 2004, s. 8.

35 For å rettferdiggiøre skilsmisse på dette grunnlaget, fortalte to dommere at de henviste til et utdrag fra sura 2, vers 229 om at man må "beholde hustruen på skikkelig vis, eller sende henne endelig fra seg på sømmelig måte”. Tradisjonelt er dette verset blitt tolket som at mannen har ensidig rett til skilsmisse og at kvinnen behøver hans samtykke. Se Abdel-Fadil, Mona: "Whose right to divorce in contemporary Egypt?" HiO-hovedfagsrapport $2002 \mathrm{nr}$. 5, s. 72. I forbindelse med masterprosjektet mitt så jeg imidlertid at dommere påberopte seg dette prinsippet når de innvilger kvinner skilsmisse på grunnlag av psykologisk skade.

36 Dupret, Baudouin: "Inventing Sharia Egyptian judges and the Islamic legal repertoire”, artikkel presentert på konferansen for Middle East Association (MESA), I997, s. 8.

37 Cuno, Kenneth: "Divorce and the fate of the family in modern Egypt”, kommende.

38 Abu-Lughod, Lila: "The marriage of feminism and islamism in Egypt: selective repudiation as a dynamic of postcolonial cultural politics" $\mathrm{i}$ «Remaking women: Feminism and modernity in the Middle East. Lila Abu-Lughod (red.). The American University in Cairo Press, I998, s. 243 .

39 Mye tyder på at kjernefamilien med ekteskap på grunnlag av kjærlighet er blitt det normative ideal blant store deler av befolkningen. Selv om forskning har ment å se tendenser i retning av et slik ideal blant middel- og øvre klasser, er det blitt ansett som noe uvanlig blant de urbane lavere klasser. Ifølge Inhorn (เ996: I48) er imidlertid dette idealet også utbredt blant ubane fattige. Inhorn, Marcia Claire: "Infertility and patriarchy". University of Pennsylvania Press, I996, s. I48. I tillegg til de ovenfor nevnte diskurser, er endringene i familiens struktur trolig knyttet til sosiale og økonomiske forhold som rask urbani- sering i etterkant av den andre verdenskrig, industrialisering, økning i utdannelse, migrasjon og økt arbeid i offentlig sektor. Cuno, Kenneth: "Divorce and the fate of the family in modern Egypt", kommende.

40 Fargues, Philippe: “Terminating marriage” i «The new Arab family». Nicholas S. Hopkins (red.). Cairo papers in social sciences, volumr 24, nr. I og 2, vår og sommer 2003, S. 25 I.

4I Ibid., s. 267.

42 "Al- Adl Bayn al-Zawgat: Kayfa Yatahakak", i Al-Ahram al massai, Io. II. I995, s. 6. 